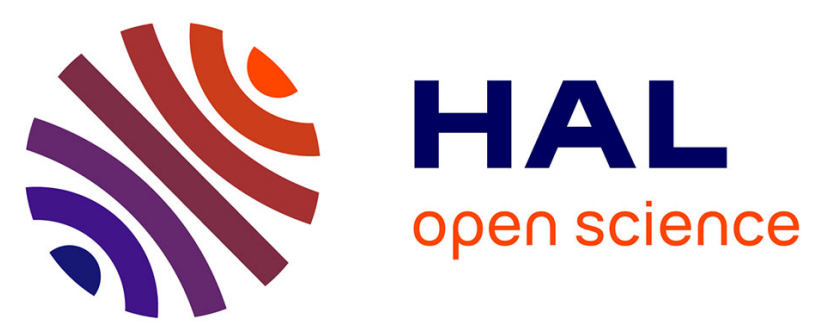

\title{
The capability approach as a framework for assessing the role of microcredit in resource conversion: the case of rural households in the Madagascar highlands
}

Sandrine Michel, Holimalala Randriamanampisoa

\section{- To cite this version:}

Sandrine Michel, Holimalala Randriamanampisoa. The capability approach as a framework for assessing the role of microcredit in resource conversion: the case of rural households in the Madagascar highlands. Oxford Development Studies, 2017, pp.1 - 21. 10.1080/13600818.2017.1368471 . hal01681797

\author{
HAL Id: hal-01681797 \\ https://hal.science/hal-01681797
}

Submitted on 11 Jan 2018

HAL is a multi-disciplinary open access archive for the deposit and dissemination of scientific research documents, whether they are published or not. The documents may come from teaching and research institutions in France or abroad, or from public or private research centers.
L'archive ouverte pluridisciplinaire HAL, est destinée au dépôt et à la diffusion de documents scientifiques de niveau recherche, publiés ou non, émanant des établissements d'enseignement et de recherche français ou étrangers, des laboratoires publics ou privés. 


\title{
The capability approach as a framework for assessing
}

the role of microcredit in resource conversion:

\section{The case of rural households in the Madagascar highlands}

\section{Sandrine Michel $^{1}$ \& Holimalala Randriamanampisoa ${ }^{2}$}

\begin{abstract}
:
This article applies the capabilities approach in order to analyse microcredit as a tool for resource conversion permitting poor households to take advantage of latent opportunities. This approach calls for linking microcredit with the choices of the poor themselves. A sample of 290 rural households from the Madagascar highlands has been surveyed two consecutive years. To characterize the dimensions of poverty based on social practices of the poor and to inform about the most relevant dimensions available for a conversion process, data have been processed by a factor analysis. A hierarchical classification then permits the distribution of the households over three capabilities levels. Finally, an ordered multinomial logit brings out how microcredit influences the likelihood that a household receiving such a loan will reach a higher capability level. The main findings indicate that the microcredit represents a robust means to obtain a higher level of capability regardless the starting situation. Moreover, when the process of borrowing endures, poor households enter into a learning process which increases the effect of microcredit. Regardless of the gender of the household head, microcredit increases the probability to reach an enhanced level of capability, except for the poorest household headed by a woman. The education of the head of household improves the effect of microcredit only if the productive system implemented needs competences related to the educational attainment.

JEL classification: O12, I32, G21
\end{abstract}

Keywords: Multidimensional poverty, Capability approach, Microcredit, Resource conversion process

\footnotetext{
${ }^{1}$ ART-Dev, University of Montpellier, Montpellier, France ; sandrine.michel@umontpellier.fr

${ }^{2}$ University of Antananarivo,Antananarivo, Madagascar ; hollymalala@gmail.com
} 


\section{Introduction}

Changes in the concept of poverty are inseparable from changes in the analyses of development. It has been recognised since the late 1980s that both the state, in a carefully delimited form, and public institutions can serve as facilitators for the actions of individuals. These individual are considered responsible for their development because they undertake initiatives to maximise the value of their personal endowments. Microcredit emerged on the international stage in this context. Initially conceived as a universal tool for development, it is now seen as a new practice for combating poverty. However, the presumed tie between the reduction of poverty and microcredit warrants critical examination. Studies assessing the impact of microcredit on the income of poor individuals or households in fact yield contradictory findings (MacGregor et al., 2000; Karlan \& Zinman, 2011). In addition, a reading focused on attainment does not permit an assessment of microcredit in terms of the possibilities it might open up for them (Razafindrakoto \& Roubaud, 2005).

The ambiguity surrounding microcredit can be repositioned within the broader issue of the definition of poverty. If the latter's multidimensional nature has come to be accepted (World Bank, 2000), this consensus has not put an end to the debates, which are now focused on questions of measuring (Comim, 2008; Ravallion, 2011; Basu, 2013). In one approach, the measure aggregates the attainment obtained in different dimensions; these are weighed through prices or imputed values and then discussed in relation to a poverty line. In another, the measurement places the emphasis on the poverty levels reached in the different dimensions and then aggregates the specific dimensions of deprivation in an indicator. Within each dimension, the weights of deprivation are defined as distances from a poverty line. In both types of measuring, what remains subject to debate is the determination of the weights. In the first case, the prices or imputed values make it possible to objectify them through the social practices of the poor; in the second, the weights are more dependent on the analyst's choice.

Microcredit is no exception to this dilemma. Its multidimensional nature is undeniable. In 
terms of attainments through household income, its impact is mixed but its assessment is based on dimensions which can be correctly weighed through prices. But, as far as we know, the literature neither identifies a link between microcredit and the decrease of privations nor any instrument to document it. To assess this impact, this article proposes to analyse microcredit as a vehicle for converting the resources of poor households. The assumption is as following. Given a state of poverty of households and thanks to microcredit, this conversion process should allow poor households to develop new resource arrangements permitting them to realise latent opportunities in order to attain a higher level of well-being. Methodologically, this assumption implies relating microcredit to the choices of the poor themselves and rendering it in an appropriate measurement.

To this end, section 2 argues for the use of the capabilities approach within a multidimensional measurement of poverty through the need to root the analyses in the choices made by the poor. Microcredit is seen as a vehicle for these choices. Using the case of poor rural households in the highlands of Madagascar, section 3 sets out the methodological framework which allows the question of resource conversion to be addressed in terms of the choices of the poor. The dimensions of household poverty, their weights and the resources likely to enter into a conversion process are established in order to obtain a multidimensional typology of the households' capabilities. Section 4 tests the potential contribution of microcredit to the reduction of household poverty and discusses the findings.

2. Multidimensional poverty and the use of the capabilities approach to analyse microcredit as an instrument for combating poverty

Multidimensional approaches to poverty permit a better identification of poor populations. They are intended to get beyond the limitations of approaches based on monetary metrics, which do not reflect the hardships suffered by poor households.

2.1 Measuring multidimensional poverty: a lack of consensus 
Multidimensional approaches associate poverty with a deprivation of well-being. Their conceptualisation has generated variants which have come to complicate the analysis of poverty. Thus, beyond income alone, factors such as insufficient resources (including nonmonetary ones), social exclusion and subjective poverty (Fusco, 2007) have gradually been integrated. Multidimensionality allows the poor to be situated within an otherness relative to the rest of the society. Indeed, regardless of the care given to defining a poverty line, it is difficult to find an indisputable cut-off point between the poor and the non-poor. One alternative to such a vision is the idea of a poverty continuum (Chiappero-Martinetti, 2006), which permits individuals to be distributed along a continuum going from minimum to maximum well-being. This means that a poor household or individual can go from one state of poverty to another. But in practice, the multidimensional nature of poverty remains difficult to measure.

The choice of the dimensions to be used is subject to considerable debate. Some of them are considered to provide better information than others but one of the fundamental problems raised by multidimensional poverty is the difficulty, if not the impossibility, of grasping all its facets simultaneously. Whatever the approach adopted, each dimension is associated with a particular aspect of well-being. In theory, these dimensions can yield infinite combinations but there is no consensus about which ones should be included because there is no universal definition of a good life. Even if the definition of a threshold of multidimensional poverty is sometimes better for informing for policy decisions, the overall difficulty still stands (Basu, 2013).

The index selected to measure multidimensional poverty is also subject to debate. Here, the question is whether a single index can capture everything that is important for the individual and thus lay claim to a certain universality. The Multidimensional Poverty Index has made such a proposal (Alkire \& Foster, 2011). An index is defined by its content but also its aggregation principle, which can address attainments or deprivations. In the case of attainments, prices objectivise the social practices of the poor and their exclusion when it is impossible to pay the price. In the case of deprivations, the choice of the 
dimensions and weights most often depends on the analyst whose choices mark his or her reading of these social practices. ${ }^{3}$ A frequent criticism concerns the justification of the weights ultimately chosen and therefore the often exogenous nature of the measure compared to the objectivity of prices for weighing attainments (Ravallion, 2011).

To improve their effectiveness, multidimensional analyses need to increase the consistency between the weights of the variables representing the dimensions of well-being and the choices of the poor themselves. It should also be kept in mind that empirical research on the question of poverty does not seek to develop a perfect indicator but to come up with measurements that provide a more solid basis for policies combating poverty. The dimensions chosen and the methods implemented to select them thus become essential issues in the analysis and measurement of poverty. In this sense, the capabilities approach provides an alternative in that it allows the choices of the poor to be integrated into the analysis.

2.2 The capabilities approach as a framework for analysing multidimensional poverty: the importance of the individual's choice

For Sen, the notion of well-being is not based exclusively on wealth but on each person's capacity. For a given individual, the profitable nature of a resource therefore depends on both the use made of it and his or her circumstances at the time of this use (Sen, 1992). Two new elements are thus added to the analyses of well-being: first, the heterogeneousness of individual characteristics and the specific features of the individual's socio-economic context, and second, the intrinsic value of each person's freedom to choose and attain. However, studying multidimensional poverty through the capabilities approach is a complicated exercise because it describes multi-faceted concepts which are interrelated in ways that are neither obvious nor particularly easy to measure.

Like multidimensional analyses of poverty, the capabilities approach takes several

\footnotetext{
${ }^{3}$ In the case of the MPI, ten indicators grouped into three dimensions have been chosen. Each dimension is given an equal weight.
} 
dimensions of well-being into account but, according to Sen (1985), poverty can be defined as a lack of real individual freedom. He insists on the extent of the freedom of choice individuals possess and which are potentially accessible in order to lead a decent life within their environment. Individuals must be able to make free choices in an autonomous way but these choices must also be real (Sen, 1992). In this context, the capabilities approach takes on its full meaning as an analytical framework for the study of multidimensional poverty.

In his analysis, Sen draws a distinction between means and ends. In other words, he distinguishes an analysis of means in terms of attainment and possibilities from a analysis whose ultimate meaning would depend on the specific end associated with the individual's choice. The capabilities approach has an immediate application in the way economic development and poverty are perceived. Within such a framework, a policy for combating poverty seeks to strengthen individual capabilities or, more precisely, to develop the real freedom of action and being which each individual should enjoy by virtue of his or her status as a person or social actor (Dubois \& Rousseau, 2008).

From this standpoint, the literature on the capability approach concludes that microfinance is a relative failure in reducing poverty regarding the expansion of real freedom (Fraser 2010, Tseng 2011) with a small exception in relation to basic capabilities such as education and health (Cabraal 2011). In contrast, these studies agreed on the contribution of microcredit in poverty reduction regarding attainment, although weak. In this context, this research proposes to consider microcredit as a vehicle promoting individual choice within a process of converting a resource in order to improve well-being. Such an approach introduces an unprecedented connection between a possession and what it permits the owner to be or do and which characterises the individual's living conditions. The conversion process thus assumes a central role in the fulfilment of capabilities. 
2.3 Microcredit: a vehicle for activating individual choices

Microcredit was initially considered as a tool for reducing poverty and thus allowing its beneficiaries to improve their well-being (UN, 2005). This presumed relationship has given rise to numerous controversies, however, and no analysis has proven satisfactory. The many household debt crises of the beneficiaries, for example, have challenged the argument that microcredit would permit the integration of millions of people excluded from the formal banking system because of their lack of guarantees and the high transaction costs (Littlefield et al., 2003). The best-know case is that of Indian microfinance (Sriram, 2010).

Another question bearing on the extent of the effects transposes microcredit into the field of multidimensional poverty. Several studies, conducted on different continents, show that the actions of microfinance institutions have obtained impressive results, both economically, with positive impacts on income level and the ability to save, and socially, with improved school enrolment for children, access to healthcare and upgraded housing (Boyé et al., 2006). But other studies show, on the contrary, that the effects of microfinance can at best be measured in terms of better management of family cash flow and, in certain cases, by an increase in family assets and consumption (Roodman \& Morduch, 2010).

Last of all, microcredit is regularly examined from the standpoint of gender relations. In a context of 'feminisation of poverty' (World Bank, 2003), microfinance promotes women's empowerment (Swain \& Wallentin, 2009). This argument is sustained by some studies (Yunus, 2006) but such findings are not generalisable, for some women have in fact faced 'great disillusionment' in terms of economic well-being (Guérin et al., 2013).

Methodologically, it is difficult for these different analyses to establish a causal link, be it direct or indirect, between microcredit and the changes observed amongst beneficiaries. The most significant effects of microcredit are accessible at local level because the most common activities it generates are micro-activities. These often depend on the occasions that arise and the income they generate remains minuscule. But even at local level, the 
choice of the criteria for determining the areas of impact influence the findings insofar as each level brings out certain phenomena and conceals others. In addition, neither the transposition of successful programmes to a larger scale (Hulme, 2000) nor the comparison of impact areas of similar scale suffices to obtain robust results (Chliova et al., 2014). The causal relationship between microfinance and poverty thus seems inherently situated, with a close dependence on local contexts (Banerjee, 2013).

The uncertainties of this initial conceptualisation of microcredit means than an enquiry into its effect on the poor must simultaneously address the problem of the relative impact of the different financial services, the multidimensionality of the poverty and the choice of the evaluation criteria (Comim, 2007). The study of the impact of microcredit thus calls for a framework permitting an overall assessment. In our case, we have opted for the capabilities approach.

It follows that the focus is not the credit itself but the attainments it will permit within a well-defined context and in relation to the individual's characteristics. This presumes identifying the needs of target populations and understanding how these populations make microcredit a vehicle for attainment. In this sense, microcredit remains a complementary element which can permit the mobilisation of other variables useful for vulnerable populations because poverty is not only a problem of income. Rather than being a financial tool alone, microcredit would then become a way of enlarging the opportunities and means made available to targeted individuals.

\section{Microcredit and capabilities: The issue of conversion and the choice of the poor} as a methodological constraint

Within the framework of the capabilities approach, in order to analyse microcredit as a tool for resource conversion, we must show that it allows each household to effect an alternative arrangement of its resources. Microcredit would thus make latent opportunities attainable with the aim of attaining a higher level of well-being. 
In the case at hand, such a vision of microcredit presumes first of all associating the living conditions of the poor rural households studied within multidimensional categories describing their well-being. During this stage, the expert's viewpoint, which is often restricted by the data, remains decisive. But in order to analyse microcredit as a conversion tool, it is also necessary to use methods which bring out the poor households' choices.

3.1. Household living conditions in context: establishing the dimensions of poverty In terms of methodology, Sen provides a justification of well-being on the basis of broader dimensions than those of monetary poverty but gives no indication of the way these dimensions should be chosen (Robeyns, 2008). According to Sen (2004), the relevant dimensions and variables are brought out by the specific, context-sensitive applications. In the capabilities approach, therefore, the important elements are not the variables themselves but the procedures leading the analyst to select them. Robeyns (2005), following Alkire (2002), insists on the fact that such procedures cannot simply provide instrumental information but should have an intrinsic value (Sen, 1999). Here, the role of the analyst is determinant.

In order to determine these dimensions of well-being, we use the literature specific to poverty in Madagascar (Cherel-Robson and Minten, 2003). This allows us to describe the households' living conditions and thus to organise their different resources so as to obtain a multidimensional representation of poverty which favours information with intrinsic value. In Madagascar, agriculture is a key economic sector but its inadequate performances since the 1950s have not been able to accommodate demographic growth (Dabat et al., 2008) or to reduce the widespread poverty affecting up to $77 \%$ of the rural populations (Maret, 2009). For rural households, the main causes of poverty are, first of all, insufficient resources, followed by the highly seasonal nature of the principal productive activity, rice growing, and consequently a considerable fluctuation in income, but also the fact of being continuously confronted by exogenous shocks (Dostie, 2002).

Amongst them, we only keep those for which the households can develop their own 
responses. ${ }^{4}$ The regular shocks are thus tied to the volatility of prices for rice - or other substitutable goods - during the hunger gap between two yearly crops. This cyclical episode is all the more important because the rural households are often net rice purchasers. ${ }^{5}$ Idiosyncratic shocks, meanwhile, concern events tied to the life cycle, such as death, illness, accidents or separation, or to social instability (job losses, theft, etc.).

These different elements have led us to select the following dimensions for characterising the poverty of rural Malagasy households :

- the structure of the households,

- their monetary resources,

- the resources serving to protect themselves from exogenous shocks

- their productive activities, dominated by rice growing. This specificity of the productive dimension influences all the others and gives the research its situated character, in keeping with the intrinsic nature of the variables.

We characterise these different dimensions through data from a panel survey studying the impact of the Cecam mutualist network on rural households of the Malagasy highlands (Wampfler et al., 2008). ${ }^{6}$ The households surveyed were selected on a random basis within two rural regions, Vakinankarata and Alaotra, and concern five Cecam savings banks. The survey was conducted in two stages. Between 2003 and 2005, data was collected on the rural agricultural economic systems which form the basis of the financial institution's activities. From 2006 to 2007, the different sections dealing with household income were complemented with information on the households' practices with regards to loans and savings. In order to gain a better understanding of the households' logics concerning the Cecam network, an additional, qualitative survey drawing on the biographical method was undertaken. In this 'life story' approach, respondents indicate what they feel about their living conditions. In this way, the data on household incomes was rounded out by

\footnotetext{
${ }^{4}$ Natural and macroeconomic shocks do not enter into the analysis.

${ }^{5}$ One million Malagasy inhabitants fall below the poverty line on a seasonal basis, thus joining the nine million living this situation permanently (Dostie et al., 2002).

${ }^{6}$ The Cecam (Caisse d'Epargne-Crédit Agricole Mutuel) network is Madagascar's most important farm credit institution.
} 
more detailed information on their living conditions, including their non-monetary resources and their strategies. Through this survey, a database including thirteen variables was constituted. A final round, carried out in 2007, provided data on a group of 290 households already having recourse to microcredit from the Cecam network. Among them, $29 \%$ are female-headed households.

Several factors explain the use of this survey for the empirical part of our study. First, the data was produced before the political crisis in 2009 that further aggravated the situation of vulnerable households. The conditions for access to microcredit apparently became more severe as well. We can thus consider that the data from this survey converge with the structural features of the situation of rural households in the Madagascar highlands (Minten, 2006). It should be noted as well that the political instability in Madagascar has not permitted the launching of the second wave of surveys. In addition, although the theoretical framework of the survey does not refer to capabilities, the variables introduced gives us access to detailed information on household living conditions. These data, although secondary (Chiappero-Martenetti, 2000), provide a real opportunity for testing our central hypothesis on microcredit as a tool for converting resources in order to improve household well-being through access to a higher capability level. For our purposes, it is thus sufficient to use the data from the final year of the survey, which are the most complete with regards to the recourse to microcredit.

In order to explore the way microcredit furthers conversion processes, our empirical work has drawn on the survey data to inventory and classify the resources of rural Malagasy households according to the four dimensions of poverty indicated above. We have thus distributed the thirteen variables of the survey (each of which is disaggregated information within the database) over these four dimensions (Appendix A) on the basis of the life stories of respondent households using microcredit in the past, a method which permits the elementary variables of the database to be associated with the households' living conditions. 
Once this representation of the living conditions of the rural households is established, the next step involves determining the most significant resources for the improvement of wellbeing through a conversion process supported by microcredit.

\subsection{Multidimensional typology of capabilities levels}

The conversion of resources is tied to the household's possibility of acting freely and thus being able to link access to microcredit with an alternative arrangement of its resources in order to increase its level of well-being. It is therefore within the context of capabilities that microcredit becomes a meaningful tool for reducing the poverty of rural households.

In methodological terms, assessing the attainment of this objective depends on two elements. First, it is necessary to measure the capabilities themselves. Since these are not directly observable, analysts utilise indirect means of data collection. Information on the functionings achieved is at least as adequate as that on capabilities, because the person's choice is clearly taken into account (Sen, 1985). Indeed, the functionings describe an individual's different ways of doing and being, his or her own attainments determined by the particular way of attributing functions to the assets at his or her disposal. In this respect, functionings offer a good indication of individual choices (Sen, 1999). The important thing is to bring out the alternatives available at the time of that choice (Sen, 1992). Our empirical section uses the functionings achieved in order to assess the households' capabilities.

Second, it is necessary to employ a method for describing the way household resources are arranged in the different dimensions. The attribution of relative weights to the different functionings and dimensions is decisive for the representation of poverty. Once the structure of the poverty is known, the dimensions most responsive to conversion are selected. Two multivariate approaches serve this objective by yielding fairly close results (Lelli, 2008). Factor analysis emphasises the weighing of functionings, whilst fuzzy sets theory is more suitable for the analysis of individuals' transitions between capabilities. The advantage of factor analysis is to rank the resources of any basket while that of fuzzy sets 
theory is to inform people's intuitions and thinking processes when confronted with fuzzy categories in reality. Insofar as the objective of the capability approach is to privilege individual choice rather than a prior list on individual privations (Alkire 2002), each method documents useful aspects of the conditions of poor household. Thus, fuzzy sets theory provides a description of the movement over a poverty continuum and therefore informs how a household manages its membership function off fuzzy categories. On the contrary, factor analysis offers a weighing household resource without a priori assumption and therefore favours their practices.

Given our objective of testing how resources are rearranged by households themselves in order to activate latent opportunities through microcredit, we have opted for factor analysis. This method of reducing variables allows us to identify the functionings involved. Amongst the variables forming the dimensions which describe the situation of a poor household, a variable is thus selected when it influences the determination of that household's living conditions. What is taken into account is the value a household attributes to a good, or to possessing it, but only insofar as this permits the household to attain an objective it deems important. The method thus allows the choices of the poor to be considered within the weighing of the different resources and therefore in the elaboration of the capabilities levels.

Drawing on categorical data, we use Multiple Correspondence Factor Analysis (MCFA) (Escofier \& Pagès, 2008) to describe the relationships between the variables observed for all the households surveyed in order to achieve an objective selection of variables. After the differences between the table of observations and the theoretical table of total independence are established, the method's matrix formulas distribute these differences between two individuals for a given modality relative to the total number of individuals. The inertia, close of the variance for multivariate analyses, is thus assigned by successive passages on the basis of their complementarity and overlap. Insofar as axes describe a decreasing dispersion of functioning, the first ones are the most relevant about the heterogeneity between individuals. 
Table 1. Contribution of the active variables in 2007

\begin{tabular}{|c|c|c|c|c|c|c|c|c|}
\hline Functioning & Modality & $\begin{array}{l}\text { Relative } \\
\text { weight }\end{array}$ & $\begin{array}{l}\text { Distance at } \\
\text { the outset }\end{array}$ & Axis 1 & Axis 2 & Axis 3 & Axis 4 & Axis 5 \\
\hline \multirow{4}{*}{$\begin{array}{l}\text { Household size } \\
\text { (Number of } \\
\text { members) }\end{array}$} & 4 & 0.596 & 14.2632 & 2.54 & 0.73 & 13.2 & 1.27 & 0.03 \\
\hline & $4-6$ & 4.357 & 1.08633 & 1.59 & 0.46 & 0.02 & 3.33 & 0.26 \\
\hline & $7-10$ & 3.197 & 1.84314 & 2.02 & 0.18 & 0 & 0.1 & 0 \\
\hline & $>10$ & 0.94 & 8.66667 & 1.85 & 0 & 9.95 & 13.02 & 1.3 \\
\hline \multirow{4}{*}{$\begin{array}{c}\text { Age of } \\
\text { household } \\
\text { head (years) }\end{array}$} & $<35$ & 1.223 & 6.4359 & 5.19 & 0.06 & 0.39 & 0.67 & 2.02 \\
\hline & $35-50$ & 4.859 & 0.87097 & 0.04 & 0 & 2.79 & 1.46 & 0.02 \\
\hline & $51-60$ & 2.508 & 2.625 & 2.27 & 0.24 & 2.26 & 6.77 & 0.12 \\
\hline & $>60$ & 0.502 & 17.125 & 0.22 & 0.8 & 0.74 & 0.62 & 3.48 \\
\hline \multirow{4}{*}{$\begin{array}{c}\text { Area cultivated } \\
\text { in ha } \\
\text { (including } \\
\text { tenant farming) }\end{array}$} & $<1$ & 2.32 & 2.91892 & 12.91 & 3.61 & 0.01 & 0 & 0.02 \\
\hline & $1-4$ & 5.423 & 0.6763 & 1.32 & 4.22 & 0.07 & 0.28 & 0.67 \\
\hline & $5-7$ & 0.784 & 10.6 & 1.91 & 0.19 & 0.02 & 0.01 & 3.72 \\
\hline & $>7$ & 0.564 & 15.1111 & 4.37 & 4.01 & 0.72 & 2.74 & 0 \\
\hline \multirow{4}{*}{$\begin{array}{c}\text { Number of } \\
\text { family farm } \\
\text { workers }\end{array}$} & 1 & 1.693 & 4.37037 & 6.18 & 8.13 & 1.74 & 0.08 & 0.53 \\
\hline & 2 & 3.292 & 1.7619 & 0.65 & 1.75 & 0.01 & 9.91 & 2.04 \\
\hline & 3 & 1.505 & 5.04167 & 1.19 & 2.82 & 2.4 & 0.72 & 0.04 \\
\hline & 4 and + & 2.602 & 2.49398 & 4.34 & 0.22 & 5.54 & 7.15 & 0.75 \\
\hline \multirow{4}{*}{$\begin{array}{c}\text { Temporary } \\
\text { employee } \\
\text { (Number of } \\
\text { hrs/yr) }\end{array}$} & $(0-30]$ & 2.351 & 2.86667 & 6.21 & 0.9 & 0.26 & 4.68 & 0.27 \\
\hline & ]30-80] & 1.975 & 3.60317 & 0.03 & 1.89 & 0.2 & 2.37 & 14.27 \\
\hline & ]80-160] & 1.787 & 4.08772 & 0.64 & 0.01 & 0.77 & 0.28 & 2.36 \\
\hline & $>160$ & 2.978 & 2.05263 & 2.12 & 3.54 & 0.35 & 0.07 & 5.53 \\
\hline \multirow{4}{*}{$\begin{array}{c}\text { Use of } \\
\text { fertiliser } \\
\text { (Number) }\end{array}$} & 0 & 2.1 & 3.32836 & 9.72 & 0.48 & 0.64 & 0.07 & 0.76 \\
\hline & 1 & 3.229 & 1.81553 & 0.45 & 0.81 & 5.15 & 2.11 & 4.32 \\
\hline & 2 & 2.006 & 3.53125 & 1.25 & 0 & 1.83 & 0.38 & 0.9 \\
\hline & 3 and + & 1.755 & 4.17857 & 1.7 & 0.17 & 0.91 & 1.05 & 7.6 \\
\hline \multirow{2}{*}{ Cash savings } & Yes & 5.611 & 0.62011 & 1.57 & 1.85 & 0.01 & 0.29 & 0.02 \\
\hline & no & 3.48 & 1.61261 & 2.54 & 2.98 & 0.01 & 0.47 & 0.03 \\
\hline \multirow{4}{*}{$\begin{array}{l}\text { Disposable } \\
\text { income } \\
\text { (in } 10^{3} \text { ariari) }\end{array}$} & [46-820] & 2.288 & 2.9726 & 1.75 & 7.68 & 2.79 & 4.7 & 0 \\
\hline & [820-1800] & 2.351 & 2.86667 & 0.36 & 1.74 & 0.09 & 1.71 & 5.73 \\
\hline & [1800-3400] & 2.132 & 3.26471 & 0.1 & 0.01 & 8.62 & 3.16 & 4.74 \\
\hline & $>3400$ & 2.32 & 2.91892 & 1.04 & 15.85 & 2.1 & 0.75 & 0.08 \\
\hline
\end{tabular}




\begin{tabular}{|c|c|c|c|c|c|c|c|c|}
\hline \multirow{4}{*}{$\begin{array}{l}\text { Diversification } \\
\text { (Number of } \\
\text { activities) }\end{array}$} & 1 farming & 1.473 & 5.17021 & 0.87 & 2.01 & 17 & 0.21 & 0.02 \\
\hline & +1 occasional & 1.63 & 4.57692 & 0.38 & 3.7 & 0.07 & 7.11 & 6.39 \\
\hline & +1 permanent & 3.166 & 1.87129 & 0.87 & 0.62 & 1.2 & 5.59 & 1.28 \\
\hline & $\begin{array}{l}+1 \text { occasional } \\
+1 \text { permanent }\end{array}$ & 2.821 & 2.22222 & 1.43 & 2.73 & 2.63 & 0.02 & 0.39 \\
\hline \multirow{4}{*}{$\begin{array}{c}\text { Self- } \\
\text { sufficiency in } \\
\text { rice (Number } \\
\text { of months) }\end{array}$} & $\leq 3$ & 1.254 & 6.25 & 7.49 & 5.15 & 2.33 & 0.81 & 4.45 \\
\hline & ]3-6] & 0.721 & 11.6087 & 0.02 & 0.15 & 4.57 & 6.34 & 4.41 \\
\hline & ]6-9] & 1.254 & 6.25 & 0.48 & 1.69 & 2.64 & 1.93 & 7.99 \\
\hline & $>9$ & 5.862 & 0.5508 & 2.66 & 0.34 & 4.87 & 0.03 & 1.14 \\
\hline \multirow{4}{*}{$\begin{array}{c}\text { Assets }\left(10^{3}\right. \\
\text { ariari) }\end{array}$} & [100-800] & 2.288 & 2.9726 & 5.11 & 1.67 & 0.23 & 3.31 & 8.28 \\
\hline & ]800-1800] & 2.288 & 2.9726 & 0.03 & 0.98 & 0.17 & 4.4 & 1.98 \\
\hline & ]1800-3700] & 2.194 & 3.14286 & 2.17 & 2.11 & 0.54 & 0.02 & 2.06 \\
\hline & $>3700$ & 2.32 & 2.91892 & 0.43 & 13.53 & 0.61 & 0.02 & 0 \\
\hline
\end{tabular}

* $=$ revenue (quantities produced ${ }^{*}$ price) -expenses +other revenues (gifts, transfers, etc.) in 1,000s of ariari

Two active variables Education level of the household head and Number of permanent employees were eliminated because they did not reach the confidence level at 5\%. 11 active variables have therefore been ranked.

In order to determine the most relevant functioning, as well as their attachment dimension, the first two axes are selected. Indeed, they present the greatest explanatory power of household heterogeneity and, consequently, concentrate the greatest deprivations on which households are likely to act through a conversion process of resources.

Table 2 - Selection of functionings and dimensions more relevant in 2007

\begin{tabular}{|c|c|c|c|}
\hline Functioning & Dimension & Axe 1 & Axe 2 \\
\hline $\begin{array}{c}\text { House size } \\
\text { Age of household }\end{array}$ & Human & 15,72 & 2,47 \\
\hline $\begin{array}{c}\text { Area cultivated } \\
\text { Family farm workers } \\
\text { Temporary employees } \\
\text { Use of fertiliser }\end{array}$ & Production & 54,99 & 32,75 \\
\hline $\begin{array}{c}\text { Cash saving } \\
\text { Disposable income }\end{array}$ & Revenu & 7,36 & 30,11 \\
\hline $\begin{array}{c}\text { Diversification } \\
\text { Self-sufficiency in rice } \\
\text { Asset }\end{array}$ & Security & 21,94 & 34,68 \\
\hline
\end{tabular}


The production and security dimensions are likely to play a determinant role in the conversion process, whereas the human and financial dimensions do not seem to contribute directly. ${ }^{7}$ This does not mean that the variables of the last two dimensions have no role in this process. In the security dimension, for example, the level of assets functioning is strongly correlated to that of income level, which comes under the financial dimension. The same is true for the farm worker variable in the production dimension, which remains dependent on the household size variable in the human dimension.

If the MCFA indicates that poor households have greater numbers of deprivations in two dimensions, it provides no information on the level of household poverty. Nonetheless, the results can be interpreted as scores prior to a classification method. Such a classification would permit the distribution of the households surveyed according to different resource levels.

On the basis of the MCFA results, the households of the sample are thus distributed through an Ascending Hierarchical Classification (AHC) which carries out successive aggregations of the households in order to compare their similarities and differences relative to the variables introduced. This permits the number of relevant classes to be established. With this method, the levels of poverty are defined ex post in function of the weight of each variable. The AHC avoids postulating any initial functional relationship between the elementary variables and the different dimensions of well-being. By attenuating the sharp division of the population which results from setting a poverty line ex ante, this method fosters a perception of poverty as a continuum.

In the end, the AHC establishes three relevant classes, each of which associates a profile of resources with a given level of household poverty. Within each class, the AHC also indicates the characteristics of the dimensions whose functionings are most likely to enter into a conversion process. We consider that these three classes describe three levels of capabilities. This multidimensional typology of households by capabilities level is qualitative in nature: high, medium and low. It gives rise to the following distribution of

\footnotetext{
${ }^{7}$ As far as this result depends on the intensity of correlations between functioning taken two by two, this result is not sensitive to the number of functioning retained per dimension since an alternative arrangement of functioning designates the same more active dimensions (see Appendix B).
} 
the sampled households:

Table 3 - Typology of households by capabilities level

\begin{tabular}{|c|c|c|c|}
\hline & $\begin{array}{l}\text { Low } \\
(23 \%)\end{array}$ & $\frac{\text { Medium }}{(55 \%)}$ & $\begin{array}{l}\underline{\text { High }} \\
(22 \%)\end{array}$ \\
\hline \multicolumn{4}{|c|}{ Security dimension } \\
\hline Diversification (number of activities) & 3 & 2 & 2 \\
\hline Self-sufficiency in rice (months) & $\leq 3$ & $4-6$ & $9-12$ \\
\hline Level of assets $\left(10^{3} \text { ariary }\right)^{*}$ & $10-800$ & $800-3,700$ & $\geq 3,700$ \\
\hline \multicolumn{4}{|c|}{ Production dimension } \\
\hline Surface cultivated (hectares) & $<1$ & 2 & $>3$ \\
\hline Farm workers (number) & 1 & $<4$ & $>4$ \\
\hline Temporary employee (days/year) & $<30$ & $80-160$ & $>160$ \\
\hline Use of fertilisers (number) & 0 & $0<\mathrm{nb}<2$ & $>2$ \\
\hline
\end{tabular}

${ }^{*} 1$ euro= 2,580.83 ariary (Source: Central Bank of Madagascar, 2007)

Type 1: Households with low capabilities

This category includes 67 households, representing $23 \%$ of our sample. At the level of the production dimension, they cultivate a small area (less than one hectare for $85 \%$ of the persons in this category). They do not use farm workers other than themselves apart from a few days of seasonal work. Nor do they use fertilisers. Generally speaking, their farming activity is characterised by the predominance of modes of production based on traditional agricultural techniques which are not extremely effective but tried and true. The majority of these cultivators are reticent about risk-taking and remain committed to on-farm consumption.

This group is the one most often resorting to diversification of its activities, a finding which is noteworthy insofar as the unidimensional literature on poverty analyses the diversification of activities as a strategy for wealthier farmers. In this case, it is viewed as a kind of insurance, where the premium corresponds to the opportunity cost tied to the low 
level of the anticipated income based on an activity less risky than farming (Barrett et al., 2001). In order to reduce the risks of losses in their assets purchases, the farmers, constrained by their aversion to risk, would tend to diversify their portfolios as much as possible. The diversification would then result from voluntary choices on their part and would concern stable activities.

By contrast, the capabilities approach demonstrates that diversification, as a strategy employed by the poorest farmers, is in fact related to the absence of choice and already reflects a certain limitation in terms of the whole of the possibilities offered. In reality, this logic comes down to a survival strategy allowing them to develop different kinds of farmlands and minimise the risks tied to specialisation (Dabat et al., 2008).

\section{Type 2: Households with medium capabilities}

This group, composed of 160 households, represents more than 55\% of our sample. Nearly all the production variables approach the average values. More than $84 \%$ of the households in this group cultivate an area of 1 to 2 hectares. With regards to production techniques, $79 \%$ of these household use at least one fertiliser. Household heads in the 35-50 age group represent nearly $60 \%$ of the total, compared to $53.5 \%$ for the entire sample.

\section{Type 3: Households with high capabilities}

This category covers 63 households, or nearly $22 \%$ of our sample. They are the households with the most developed farming activities. The heavy use of fertilising substances (chemical fertilisers, manure, improved seeds, plant protection products) demonstrates a certain mastery of farming techniques and indicates relatively substantial intensification. Concerning the financial dimension, the households in this group have significant cash resources: nearly $80 \%$ of them are in the highest income bracket of our sample. They also have a fairly high assets level, which confirms the close correlation between income level and assets level described in the literature (Dasgupta, 1993). More than 90\% of the households in this category have available rice stocks guaranteeing their consumption for at least 9 months. 
More than half the households in this group include between 7 and 10 persons. This does not correspond to what is advanced in the unidimensional literature, which maintains that the largest households are also the poorest because of the distribution of scarce resources amongst a greater number of persons (Ravallion, 1998). We show, on the contrary, that a large household can offer advantages. Each member's networks are combined in favour of the household as a whole, which thus enjoys a higher level of social capital (Bisiaux, 2011). These informal mechanisms can be decisive in day-to-day risk management and this is quite important in a context where formal insurance schemes are nonexistent or too expensive.

In order to combat their poverty, the households seek to develop their capabilities. In this context, microcredit can be analysed as a means of enlarging and strengthening these capabilities. This process can take the form of acquiring assets. Here, microcredit is no longer an end in itself, circumscribed by an approach in terms of resources, but rather, a contribution to the multidimensional analysis of poverty. In the final stage of our method, we thus study the impact of microcredit as a vehicle for choice in the process of converting resources in order to gain access to a higher capability level.

\section{Assessment of the impact of microcredit on capabilities}

In order to verify the positive role of microcredit, it is necessary to understand how a microcredit loan undertaken in the past can improve the household's present situation. Here, our study follows in the line of earlier research investigating the effectiveness of microcredit in changing the users' living conditions (Sebstad \& Chen, 1996; Littlefield et al., 2003; Goldberg, 2005).

In our study, the survey households are divided into three levels of capabilities, each of which is characterised by a group of resources and represents a level of deprivation. Our 
task is to see whether microcredit permits a household to attain a higher capability level. If this is the case, microcredit allows the household to move towards a higher level of wellbeing characterized by lower deprivations.

\subsection{Estimation of the relationship between microcredit and capabilities}

At this point we introduce an econometric strategy allowing us to understand how microcredit influences a given household's probability of attaining a higher capability level. Capability level is presented as an ordered polytomous variable. This kind of ordinal variable calls for an ordered logit model (McKelvey \& Zavoina, 1975) to estimate the relationship between household capability level and microcredit loan. We have employed a generalised ordered logit model, which is adapted to the structure of the data. ${ }^{8}$

With this method, what is modelled is not the dependent variable itself but the probability that it takes on the value 1 or 0 . In order to do so, we assume the existence of a latent variable $y^{*}$ such that: $y=1$ if $y^{*} \geq 0$ and $y=0$ if $y^{*}<0$. We then assume that this latent variable $y^{*}$ is linearly dependent on a certain number of explanatory variables.

The equation for the model is defined as follows:

$$
y_{i}=\gamma D_{i}+\chi E_{i}+\varepsilon i
$$

with $y i^{*}$ as the latent variable. It represents the three capabilities levels: low $(y=1)$, medium $(y=2)$ or high $(y=3)$ for a household $i$ in 2007.

The vectors $\gamma, \chi$ and $\varepsilon$ are the parameters to be estimated (see descriptive statistic in Appendix D).

- $\mathrm{D}$ is a vector representing the main explanatory variables including:

- The amount of the microcredit loan (for an individual $i$ in 2006). We use it in a first regression as the main interest variable.

- A second regression tests another interest variable, the number of microcredit

\footnotetext{
${ }^{8}$ An ordered logit assumes that the effect of the explanatory variables is the same for all the modalities of the variable explained. In our case, the Brant test (Appendix C) shows that this hypothesis is not verified because one explanatory variable - the events tied to the life cycle - has a different effect depending on the capability level.
} 
loans undertaken by a given person. This represents the credit history. Since the two variables are closely correlated, we do not use them in the same regression. - E represents a set of control variables, namely:

- Shocks potentially affecting the rural households. These may be, on the one hand, idiosyncratic shocks related to life-cycle events (i.e., all the expenses generated by external shocks affecting household resources, such as marriages, illnesses, deaths, etc.) or, on the other, those tied to production (very good harvests and very poor sales prices).

- Individual characteristics and microcredit-related variables. These include, for the head of household, gender and diploma, and for the microcredit loan, the number of years the beneficiary has been a member of the Cecam network.

- $\varepsilon$ represents calculation or measurement errors between observed and calculated values.

In our case, the explained variable can take three forms corresponding to the three levels of capabilities identified (low, medium or high). Since the model assumes the selection of a reference category, we use the group of households with a high capabilities level $(y=3)$. We observe that the variables act differently depending on the individuals' capabilities levels. Here, the variables increasing the probability that a household with low capabilities $(y=1)$ attains the maximum level $(y=3)$ are not the same as those for a household with an average capabilities level $(y=2)$.

\subsection{Results}

In order to show how the amount of the microcredit loan and the number of loans received influence the households' well-being through the improvement of their capabilities, we interpret the signs of the coefficients derived from the estimation.

- Regression analysis of the amount of the microcredit loan 
Table 4.1. Results of the impact of the microcredit on capabilities

Regression 1 on the amount of the microcredit loan*

\begin{tabular}{|c|c|c|c|c|}
\hline $\begin{array}{c}\text { Level of } \\
\text { Capabilities }\end{array}$ & \multicolumn{2}{|c|}{$\begin{array}{l}\mathrm{y}=1 \\
\text { Low }\end{array}$} & \multicolumn{2}{|c|}{$\begin{array}{c}\mathrm{y}=2 \\
\text { Medium }\end{array}$} \\
\hline Variables & $\begin{array}{l}\text { Coefficient } \\
\text { (Robust } \\
\text { standard error) }\end{array}$ & Marginal effects & $\begin{array}{l}\text { Coefficient } \\
\text { (Robust } \\
\text { standard error) }\end{array}$ & Marginal effects \\
\hline $\begin{array}{l}\text { Microcredit loan } \\
\text { amount (ln) }\end{array}$ & $\begin{array}{l}0.1034^{* * *} \\
(0.02523)\end{array}$ & -0.01420 & $\begin{array}{l}0.0859^{* * *} \\
(0.0239)\end{array}$ & 0.0011 \\
\hline $\begin{array}{c}\text { Years of } \\
\text { membership }\end{array}$ & $\begin{array}{l}0.0450 \\
(0.0501)\end{array}$ & -0.0062 & $\begin{array}{l}-0.0836 \\
(0.0505)\end{array}$ & 0.0189 \\
\hline Diploma & $\begin{array}{l}0.2166 \\
(0.1706)\end{array}$ & -0.0298 & $\begin{array}{l}-0.4585^{*} \\
(0.1624)\end{array}$ & 0.0996 \\
\hline Life-cycle events & $\begin{array}{l}-0.4012^{*} \\
(0.1505)\end{array}$ & 0.0551 & $\begin{array}{l}-0.2698 \\
(0.1361)\end{array}$ & -0.0140 \\
\hline Gender & $\begin{array}{l}0.8228^{* * *} \\
(0.3081)\end{array}$ & -0.1130 & $\begin{array}{l}0.1762 \\
(0.3149)\end{array}$ & 0.0862 \\
\hline $\begin{array}{l}\text { Very good } \\
\text { harvests }\end{array}$ & $\begin{array}{l}0.8425 \\
(0.3335)\end{array}$ & -0.1157 & $\begin{array}{l}0.1290 \\
(0.3001)\end{array}$ & 0.0961 \\
\hline $\begin{array}{c}\text { Very poor sales } \\
\text { prices }\end{array}$ & $\begin{array}{l}-1.854 \\
(0.7511)\end{array}$ & 0.1130 & $\begin{array}{l}-0.6101 \\
(0.3764)\end{array}$ & -0.0633 \\
\hline $\begin{array}{r}\text { Generalized Orde } \\
\text { Number of } \\
\text { Wald chi2 }(1 \\
\text { Prob }>\text { chi2 } \\
\text { Log pseudo } \\
\text { Pseudo R2 }\end{array}$ & $\begin{array}{l}\text { red Logit Estima } \\
\begin{aligned} \text { obs } & =290 \\
4)= & 79.58 \\
& =0.0000 \\
\text { likelihood }= & -245 . \\
= & 0.1487\end{aligned}\end{array}$ & 4035 & & \\
\hline
\end{tabular}

* The estimations have been adjusted for heteroscedasticity. 
The results from regression 1 show that the amount of the microcredit loan, as the main interest variable, is significant for all the households. The amount of the loan thus increases the probability of belonging to the group of households with the highest capabilities, regardless of their initial capabilities level, whether low $(y=1)$ or average $(y=2)$.

This finding is reinforced by the analysis of the marginal effects, where the amount of the microcredit loan variable is also significant. ${ }^{9}$ In the case of this variable, an increase of $1 \%$ leads to a $1.42 \%$ reduction of the probability of belonging to a low capabilities level $(y=1)$. By contrast, when this increase concerns the medium level of capabilities $(y=2)$, this relationship is less clear.

This indicates that the higher the amount of the loan, the greater the opportunities opened up for the household. This finding is worthy of further investigation because, in the case of the Cecam network, most of the larger and the longer (from 18 to 36 months in our sample) loans finance investments. Thus, the acquisition of agricultural equipment bolsters the production dimension, and that of household equipment, the security dimension (i.e., the two most enabling dimensions of capabilities). In both cases, moreover, the goods can serve as guarantees for future loans. Contrary to the joint liability scheme, the terms for loans within the Cecam network require an individual guarantee, in the form of physical assets. This guarantee can be activated later on, even for another household. But in this case, the collective guarantee is reinforced by the pledging of equipment.

The gender of the household head has a differentiating effect for the group of households with low capabilities $(y=1)$. Indeed, when the household head is male, the household has a greater probability of joining the reference group. Conversely, this probability declines when the household head is female. In most cases, women become heads of households in

\footnotetext{
${ }^{9}$ In other words, the estimated coefficients give the variation of one unit of the explanatory variable, for the value assumed by the latent variable. This serves to explain the values assumed by Y (level of capabilities with two possible forms, 1 or 2) in function of the values of $X$.
} 
circumstances marked by a deterioration of their living conditions, such as widowhood or separation. These findings are consistent with the literature on poverty: poor women are amongst the most impoverished. It should be noted, however, that the gender variable does not act on the probability that households with average capabilities will join the reference households group. Once the households' resources show a small increase $(y=$ 2), gender no longer differentiates the resource conversions permitted by the microcredit loan.

Expenditures related to life-cycle events reduce the probabilities that low-capability households $(y=1)$ will enter the reference households group. This situation corresponds in fact to income losses. In order to face up to these unanticipated events, the households dip into their savings, whether monetary or non-monetary. The analysis of the marginal effects (Table 4.1) confirms this finding by showing that the increase in these expenses leads to a $5.5 \%$ increase in the probability of belonging to the low-capability households $\operatorname{group}(y=1)$.

The diploma level reduces the probability that an average-capacity household $(y=2)$ will attain the reference group and is not significant for low-capability households $(y=1)$. Far from the standard vision that associates an increase in education level with increased wellbeing through the increase in future income (Becker, 1964), this result, following others (Pritchett, 2001), indicates that education is a conditional resource which in fact appears to be closely dependent on the other resources the poor household can gather together. If the diploma level of the household head corresponds to a level of resources allowing education to be used to advantage in the conversion process, the microcredit loan will have a favourable impact. On the contrary, a gap between the diploma level and that of the other resources is harmful to the process.

- Regression on the number of loans

Table 4.2. Results of the impact of the microcredit loan on capabilities Regression 2 on the number of loans* 


\begin{tabular}{|c|c|c|c|c|}
\hline $\begin{array}{c}\text { Level of } \\
\text { Capabilities }\end{array}$ & \multicolumn{2}{|c|}{$\begin{array}{l}y=1 \\
\text { Low }\end{array}$} & \multicolumn{2}{|c|}{$\begin{array}{c}\mathrm{y}=2 \\
\text { Medium }\end{array}$} \\
\hline Variables & $\begin{array}{l}\text { Coeff } \\
\text { (Robust } \\
\text { standard error) }\end{array}$ & Marginal effects & $\begin{array}{l}\text { Coeff } \\
\text { (Robust } \\
\text { standard error) }\end{array}$ & Marginal effects \\
\hline Number of loans & $\begin{array}{l}0.7258^{* * *} \\
(0.2089)\end{array}$ & $-0.0985^{* * *}$ & $\begin{array}{l}0.4078^{* *} \\
(0.1456)\end{array}$ & 0.0348 \\
\hline $\begin{array}{c}\text { Years of } \\
\text { membership }\end{array}$ & $\begin{array}{l}0.0282 \\
(0.0495)\end{array}$ & -0.0038 & $\begin{array}{l}-0.0903 \\
(0.0489)\end{array}$ & 0.0179 \\
\hline Diploma & $\begin{array}{l}0.1824 \\
(0.1664)\end{array}$ & -0.0248 & $\begin{array}{l}-0.4487^{*} \\
(0.1623)\end{array}$ & 0.0949 \\
\hline Life-cycle events & $\begin{array}{l}-0.3973^{*} \\
(0.1487)\end{array}$ & 0.0539 & $\begin{array}{l}-0.2505 \\
(0.1342)\end{array}$ & -0.0148 \\
\hline Gender & $\begin{array}{l}0.7689 \\
(0.3040)\end{array}$ & -0.1044 & $\begin{array}{l}0.1393 \\
(0.3125)\end{array}$ & 0.0826 \\
\hline $\begin{array}{l}\text { Very good } \\
\text { harvests }\end{array}$ & $\begin{array}{l}0.8038 \\
(0.3269)\end{array}$ & -0.1091 & $\begin{array}{l}0.1078 \\
(0.2954)\end{array}$ & 0.0923 \\
\hline $\begin{array}{c}\text { Very poor sales } \\
\text { prices }\end{array}$ & $\begin{array}{l}-1.819 \\
(0.7587)\end{array}$ & 0.1643 & $\begin{array}{l}-0.6433 \\
(0.3721)\end{array}$ & -0.0502 \\
\hline $\begin{array}{r}\text { Generalized Orde } \\
\text { Number of } \\
\text { Wald chi2( } \\
\text { Prob }>\text { chi2 } \\
\text { Log pseudc } \\
\text { Pseudo R2 }\end{array}$ & $\begin{array}{l}\text { ed Logit Estimat } \\
\text { bs }=290 \\
\text { ) }=71.97 \\
0.0000 \\
\text { ikelihood }=-249 \\
0.1377\end{array}$ & 1723 & & \\
\hline $\begin{array}{l}\text { Significance of th } \\
10 \%\end{array}$ & variables: ${ }^{* * *}$ si & ficant at $1 \%$, & ignificant at $5^{\circ}$ & * significant at \\
\hline
\end{tabular}

* The estimations have been adjusted for heteroscedasticity.

When we use the number of loans granted to the households as an interest variable, we 
find that this variable is significant for increasing the probability of being in the group of reference households, regardless of the group the person belongs to $(y=1)$ and $(y=2)$. In the case of the number of loans variable, an increase of $1 \%$ leads to a $9.85 \%$ reduction of the probability of belonging to a low capabilities level $(y=1)$ relative to the others. Furthermore, a 1\% increase in the number of loans raises the probability of belonging to a medium level of capabilities $(y=2)$ by $3.48 \%$. The fact that the number of loans obtained has a positive effect on the resource conversion process for all the households, regardless of their initial resource level, is a good example of the process through which microcredit functions over time to increase the effectiveness of the household's available resources for combating its poverty. In parallel, we find that the return of the conversion process on capabilities decreases with the household's resource level: the leverage represented by the number of loans to go from the first capability level $(y=1)$ to the second $(y=2)$ is greater than that for attaining the reference level.

As regards the control variables, for households with low capabilities levels $(y=1)$, the only significant variable is the spending related to life-cycle events, which lowers the household's probability of belonging to the reference households group. This regression by number of loans also confirms the result of the first regression concerning the disadvantageous nature of the household head's diploma level for the medium capabilities level households.

Overall, the results of this second regression are predictable in that the number of loans granted to the households is consistent with the amount of the microcredit. This step thus confirms the robustness of our results.

\section{Conclusion}

Sen's research enriches the multidimensional approach to poverty. By defining development as the augmentation of capabilities, he brings out the importance of individuals' choices. It is thus necessary for poverty measures to integrate this freedom of 
choice amongst the poor. This new vision of poverty has also led to expanding the tools for analysing such choices. Microcredit may be considered as one of them but this requires a demonstration that it permits an alternative utilisation of the households' resources in order to realise their latent opportunities and thus improve their capability levels.

Our empirical sections have attempted to address these issues. We began by characterising the poverty of the rural Malagasy households. The functioning informing the different dimensions of the poverty were weighted through a factor analysis. An Ascending Hierarchical Classification then allowed us to distribute the households according to their resource level and thus establish a multidimensional typology of their capabilities. This representation of a poverty continuum follows from various methods sharing the preference for the social practices of the households as an analytical descriptor.

This approach permits us to determine that the production and security dimensions are the most decisive for the rural households' resource conversion process. Even at this stage, however, the capabilities approach raises questions about the strategy of diversification of activities as a means of risk prevention. Indeed, the literature attributes this capacity to the most comfortable households. But in our case, diversification is in fact used by the poorest households in order to access additional, albeit uncertain, income given the impossibility of more effective choices. The most comfortable households prefer specialisation in order to implement better production strategies.

Second, our estimation of the relationship between microcredit and capabilities highlights the way resource conversion allows a household to improve its likelihood of attaining a higher level of well-being. From this standpoint, microcredit bolsters the expansion of existing activities and promotes the benefits the households can derive from them. We bring this out through a learning effect related to microcredit. Thus, we show that the access to a microcredit loan and its amount, both of which increase with the client's experience in monetary matters, permit the households to carry out investment projects generating additional income. The sensitivity of the poor to their income level, or its 
fluctuations, remains real. The reason increased income is useful is that it opens up opportunities for them as individuals within a society potentially constructed through their choices.

The relationship between education level and microcredit is more complex. In order for education to play a role in resource conversion, its level seemingly has to correspond to the productive possibilities that education could improve. Failing that, the household head's education level is not a usable resource for improving the household's living conditions. This finding should be treated with caution, however, because we have considered the education level of the household head. Moreover, our finding suggests that gender is a differentiating factor for the households with the least resources. But once women move out of the most severe poverty and acquire more resources, it is no longer determinant in their conversion process.

Our method thus refines a series of findings obtained through multidimensional analyses. For example, by guaranteeing the amount of the loan against the household's property, Cecam introduces the possibility of monetising savings considered as illiquid. This specific scheme for guaranteeing the microcredit thus offers the households new opportunities. At the same time, by rendering the reimbursement of microfinance organisations more secure, it can lead the latter to adapt their financing tools to the real needs of poor households.

These findings have been obtained within a methodological framework which limits their scope. Indeed, the available data offer favourable conditions for using a generalised ordered multinomial logit on the highest level of capabilities. The richness of these intermediate results encourages recourse to more sophisticated methods, notably in order to analyse the effects of microcredit by combining the three capabilities levels in order to study the transition from one level to another, whether upwards or downwards, as well as the households' process of accumulating capabilities over time. The results also suggest that the effectiveness of development instruments such as microcredit are sensitive to their 
setting. Their generalisation to other contexts calls for further investigation.

\section{References}

Alkire, S. (2002). Valuing Freedoms. Sen's Capability Approach and Poverty Reduction, New York \& Oxford: Oxford University Press.

Alkire, S. \& Foster, J. (2011). Counting and multidimensional poverty measurement, Journal of Public Economics, 95 (7-8), 476-487.

Banerjee, A. (2013). Microcredit Under the Microscope: What Have We Learned in the Past Two Decades, and What Do We Need to Know?, Annual Review of Economics, 5, 487-519.

Barret, C., Reardon, T. \& Webb, P. (2001). Non-farm income diversification and household livelihood strategies in rural Africa, Food Policy, 26 (4), 315-331.

Basu, K. (2013). Shared Prosperity and the Mitigation of Poverty; In Practice and in Precept, Policy Research Working Paper $n^{\circ}$ 6700, Washington: The World Bank, 1-37.

Boyé, S., Hajdenberg, J. \& Poursat, C. (2006). Microfinance, microcrédit et épargne pour le développement, Paris: Editions d'Organisation.

Cabraal, A. (2011). The impact of microfinance on the capabilities of participants, PhD Thesis, RMIT University, http://researchbank.rmit.edu.au/view/rmit:9730

Cherel-Robson, M. \& Minten, B. (2003). Risques, production agricole et pauvreté, in Minten, B., Randrianarisoa, J.-C \& Randrianarison L. (Eds). Agriculture, pauvreté rurale et politique économique à Madagascar, Cornell University, 72-77.

Chiappero-Martinetti E. (2000). A Multidimensional Assessment of Well-Being Based on Sen's Functioning Approach, Rivista Internazionale di Scienze Sociali, 108 (2), 207-239.

Chiappero-Martinetti, E. (2006). Capability Approach and Fuzzy Sets Theory, in Lemmi A., Betti, G. (Eds) Fuzzy set approach to multidimensional poverty measurement. London: Springer, 
93-113.

Chliova, M., Brinckmann, J. \& Rosenbusch, N. (2014). Is microcredit a blessing for the poor? A meta-analysis examining development outcomes, Journal of Business Venturing, http://dx.doi.org/10.1016/j.jbusvent.2014.10.003.

Comim, F. (2007). Poverty Reduction through Microfinance: a Capability Perspective, in: Balkenhol, B. (Ed). Microfinance and Public Policy, New York: Palgrave-ILO, 47-59.

Comim, F. (2008). Measuring capabilities, in: Comim, F., Qizilbash, M. \& Alkire S. (Eds). The Capability Approach: Concepts, Measures and Applications, Cambridge \& New York: Cambridge University Press, 157- 200.

Dabat, M.-H., Gastineau, B. \& Jenn Treyer, O. (2008) L'agriculture malgache peut-elle sortir de l'impasse démo-économique ?, Autrepart, 46, 189-202.

Dasgupta, P. (1993). An Inquiry into Well-Being and Destitution, Oxford: Clarendon Press.

Dostie, B., Haggblade, S. \& Randriamamonjy, J. (2002). Seasonal poverty in Madagascar: magnitude and solutions, Food Policy, 27, 493-518.

Dubois, J.-L. \& Rousseau S. (2008). Reinforcing Household's Capabilities as a Way to Reduce Vulnerability and Prevent Poverty in Equitable Terms, in: Comin, F., Qizilbash, M. \& Alkire, S. (Eds), Op. Cit., 421-436.

Escofier, B. \& Pagès J. (2008). Analyse factorielle simple et multiple: objectifs, méthode et interprétation, Paris: Dunod.

Fraser, L.-J. (2010). Amartya Sen's Capability Approach and Microfmance in Bolivia, Ph D Thesis, Carleton University.

Fusco, A. (2007). La pauvreté, un concept multidimensionnel, Paris: L'Harmattan.

Ganle, J., Afriyie, K. \& Segbefia, A. (2015). Microcredit: Empowerment and Disempowerment of Rural Women in Ghana, World Development, 66 (C), 335-345.

Goldberg, N. (2005). Measuring the impact of microfinance: taking stock of what we know, Washington DC: Grameen Foundation.

Guérin, I., Kumar, S. \& Agier I. (2013). Women's Empowerment: Power to Act or Power 
over Other Women? Lessons from Indian Microfinance, Oxford Development Studies, 41 (S1), S76-S94.

Hulme, D. (2000). Impact Assessment Methodologies for Microfinance: Theory, Experience and Better Practice, World Development, 28 (1), 79-98.

Karlan, D. \& Zinman, J. (2011). Microcredit in theory and practice: Using randomized credit scoring for impact evaluation, Science AAS, 332 (6035), 1278-1284.

Lelli, S. (2008). Operationalising Sen's capability approach: the influence of he selected technique, in: Comim, F., Qizilbash, M. \& Alkire S. (Eds), Op. Cit., 310- 361.

Littlefield, E., Morduch J. \& Hashemi S. (2003). Is microfinance an effective strategy to reach the Millennium Development Goals?, Focus note, n²4, January, Washington DC: CGAP.

Maret, F. (2009). Madagascar, in Anderson, K. \& Masters W. (Eds). Distortions to agricultural incentives in Africa, Washington D.C.: The World Bank, 101-126.

Mac Gregor, J., Mosley A., Johnson, P. \& Simanowitz, A. (2000). How can impact assessment take into account wider social and economic impacts?, Imp-Act, Working Paper, $n^{\circ} 3$, june.

McKelvey R. \& Zavoina, W. (1975). A statistical model for the analysis of ordinal level dependent variables, The Journal of Mathematical Sociology, 4 (1), 103-120.

Minten, B. (2006). The role of agriculture in poverty alleviation revisited: the case of Madagascar, Washington DC: World-Bank.

Pritchett, L. (2001). Where Has All the Education Gone? World Bank Economic Review, 15 (3), 367-391.

Randriamanampisoa, H. (2011). Microcrédit et gestion des risques : une grille de lecture par les capabilités, le cas des ménages ruraux des hautes terres de Madagascar, Ph D Thesis, University of Montpellier.

Ravallion, M. (1998). Poverty lines in theory and practice, Living Standard Measurement Study - Working Paper, n 133, Washington D.C.: The World Bank. 
Ravallion, M. (2011). On multidimensional Indices of Poverty, The Journal of Economic Inequality, 9(2), 235-248.

Razafindrakoto, M. \& Roubaud, F. (2005). Les multiples facettes de la pauvreté dans un pays en développement : le cas de la capitale malgache, Economie et statistique, 383-385, 131-155.

Robeyns, I. (2008). Sen's capability approach and the feminist, in Comim, F., Qizilbash, M. \& Alkire S. (Eds), Op. Cit., 82-104.

Roodman, D. \& Morduch J. (2010). The impact of microcredit on the poor in Bangladesh: Revisiting the evidence, NYU Wagner Research paper, $\mathrm{n}^{\circ} 2010-09$.

Sebstad, J. \& Chen, G. (1996). Overview of studies on the impact of microenterprise credit, vol. 92, Washington DC, USAID AIMS, June.

Sen, A. (1985). Commodities and Capabilities, Amsterdam: North-Holland.

Sen, A. (1992). Inequality Reexamined, Oxford: Clarendon Press.

Sen, A. (1999). Development as freedom, Oxford: Oxford University Press.

Sen, A. (2004). Capabilities, Lists, and Public Reason, Feminist Economics, 10 (3), 77-80.

Sriram, M. (2010). Microfinance: a fairy tale turns into nightmare, Economic and political weekly, 45 (43), 10-13.

Swain, R. \& Wallentin F. (2009). Does microfinance empower women? Evidence from selfhelp groups in India, International review of applied economics, 23 (5), 541-556.

Tseng C. (2011). Microfinance and Amartya Sen's capability approach, Ph D Thesis, University of Birmingham, http://etheses.bham.ac.uk/2921/1/Tseng11PhD.pdf.

United Nations (2005). General Assembly Resolution A/58/488, New-York.

Wampfler, B., Bouquet, E. \& Ralison E. (2008). Etude de l'impact du réseau des Caisses d'Epargne et de Crédit Agricole Mutuels de Madagascar- Rapport final de l'étude 2003-2007, Montpellier : Cirad.

World Bank (2000). Attacking poverty, World Development Report 2000/2001, Washington DC: The World Bank. 
World Bank (2003). Sustainable Development in a Dynamic World: Transforming Institutions, Growth and Quality of Life, World Development Report 2003, Washington DC: The World Bank.

Yunez-Naude, A. \& Taylor, JR. (2001). The Determinants of Nonfarm Activities and Incomes of Rural Households in Mexico, with Emphasis on Education, World Development, 29 (3), 561-572.

Yunus, M. (2007). Creating a World without Poverty, New-York: Public Affairs. 
Appendix A. Distribution of survey variables representing household resources within dimensions representing rural poverty in Madagascar

\begin{tabular}{|c|c|c|c|}
\hline Dimensions & Variables & $\begin{array}{c}\text { Type of } \\
\text { indicator } \\
\text { (nb of } \\
\text { modalities) }\end{array}$ & $\begin{array}{l}\text { Description of the } \\
\text { indicator }\end{array}$ \\
\hline \multicolumn{4}{|c|}{ 1. Human dimension } \\
\hline \multirow{3}{*}{$\begin{array}{l}\text { These variables provide a summary } \\
\text { description of the household's structure. } \\
\text { The age of the household head thus gives } \\
\text { information about the household's life } \\
\text { cycle whilst the size of the household } \\
\text { suggests its demographic pressure. }\end{array}$} & $\begin{array}{l}\text { 1. Education } \\
\text { level of } \\
\text { household } \\
\text { head }\end{array}$ & Categorical (4) & $\begin{array}{l}\text { None; } \\
\text { primary; } \\
\text { lower secondary; } \\
\text { upper sec. and + }\end{array}$ \\
\hline & $\begin{array}{l}\text { 2. Age of } \\
\text { household } \\
\text { head }\end{array}$ & Categorical (4) & $\begin{array}{l}<35 ; \\
{[35-50] ;} \\
{[51-60]} \\
>60\end{array}$ \\
\hline & $\begin{array}{l}\text { 3. Size of } \\
\text { household }\end{array}$ & Categorical (4) & $\begin{array}{l}<4, \\
{[4-6]} \\
{[7-10]} \\
+10\end{array}$ \\
\hline \multicolumn{4}{|c|}{ 2. Financial dimension } \\
\hline $\begin{array}{l}\text { In rural households, the earnings come } \\
\text { above all from agriculture and depend on } \\
\text { the value of their production. But the } \\
\text { households also have extra-agricultural }\end{array}$ & $\begin{array}{l}\text { 4. Disposable } \\
\text { income }\end{array}$ & Categorical (4) & $\begin{array}{l}\text { [46-820]; } \\
\text { ]820-1800]; } \\
\text { ]1800-3400]; } \\
>3400\end{array}$ \\
\hline $\begin{array}{l}\text { income stemming from the diversification } \\
\text { of activities. Monetary savings can be a } \\
\text { short-term means of protection against } \\
\text { unforeseen events and thus, for the } \\
\text { vulnerable households, it constitutes an } \\
\text { important strategy for regulating their } \\
\text { income. }\end{array}$ & 5. Cash savings & $\begin{array}{c}\text { Dichotomous } \\
\text { (2) }\end{array}$ & $\begin{array}{l}\text { Yes } \\
\text { Not }\end{array}$ \\
\hline
\end{tabular}




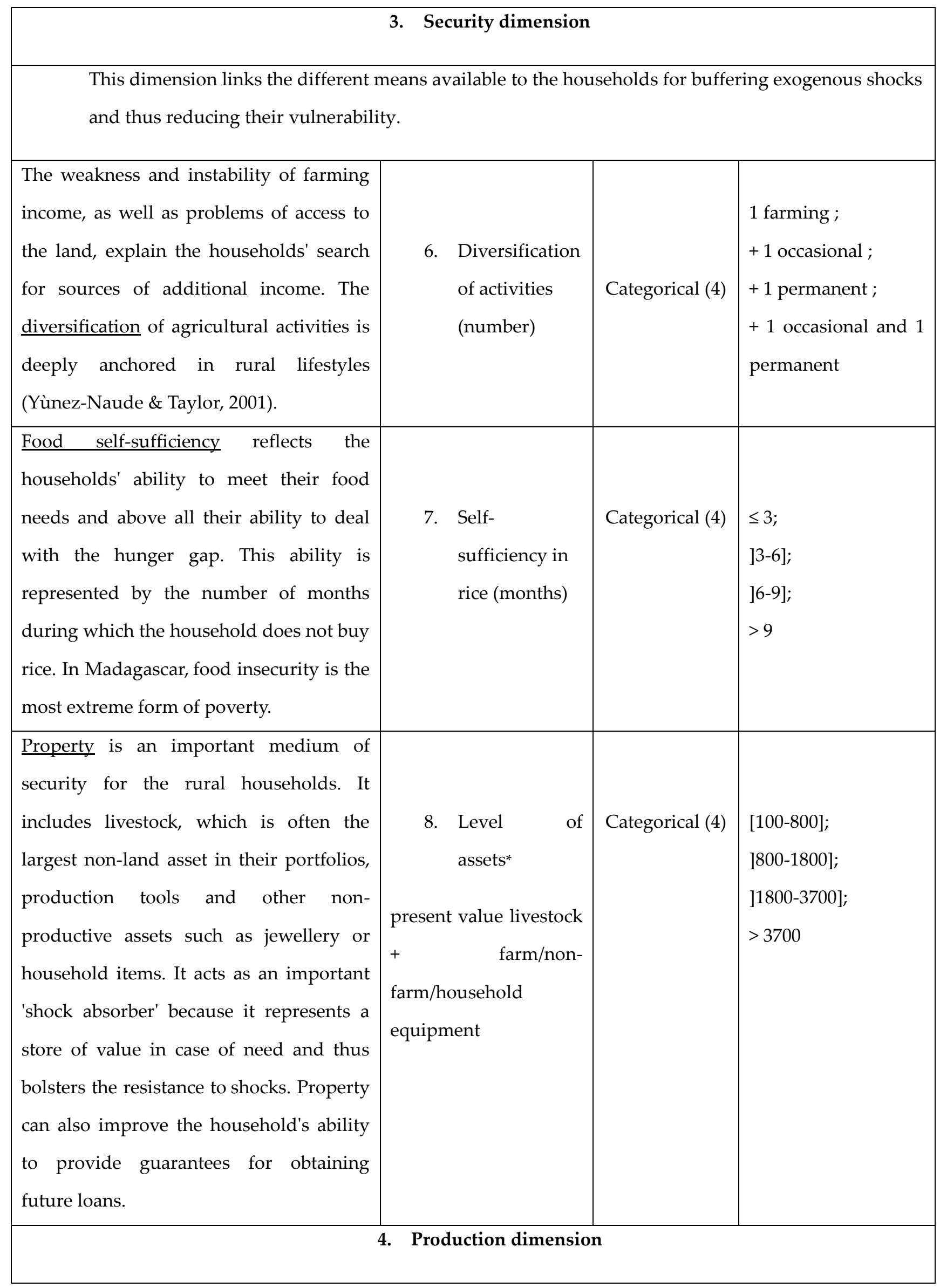




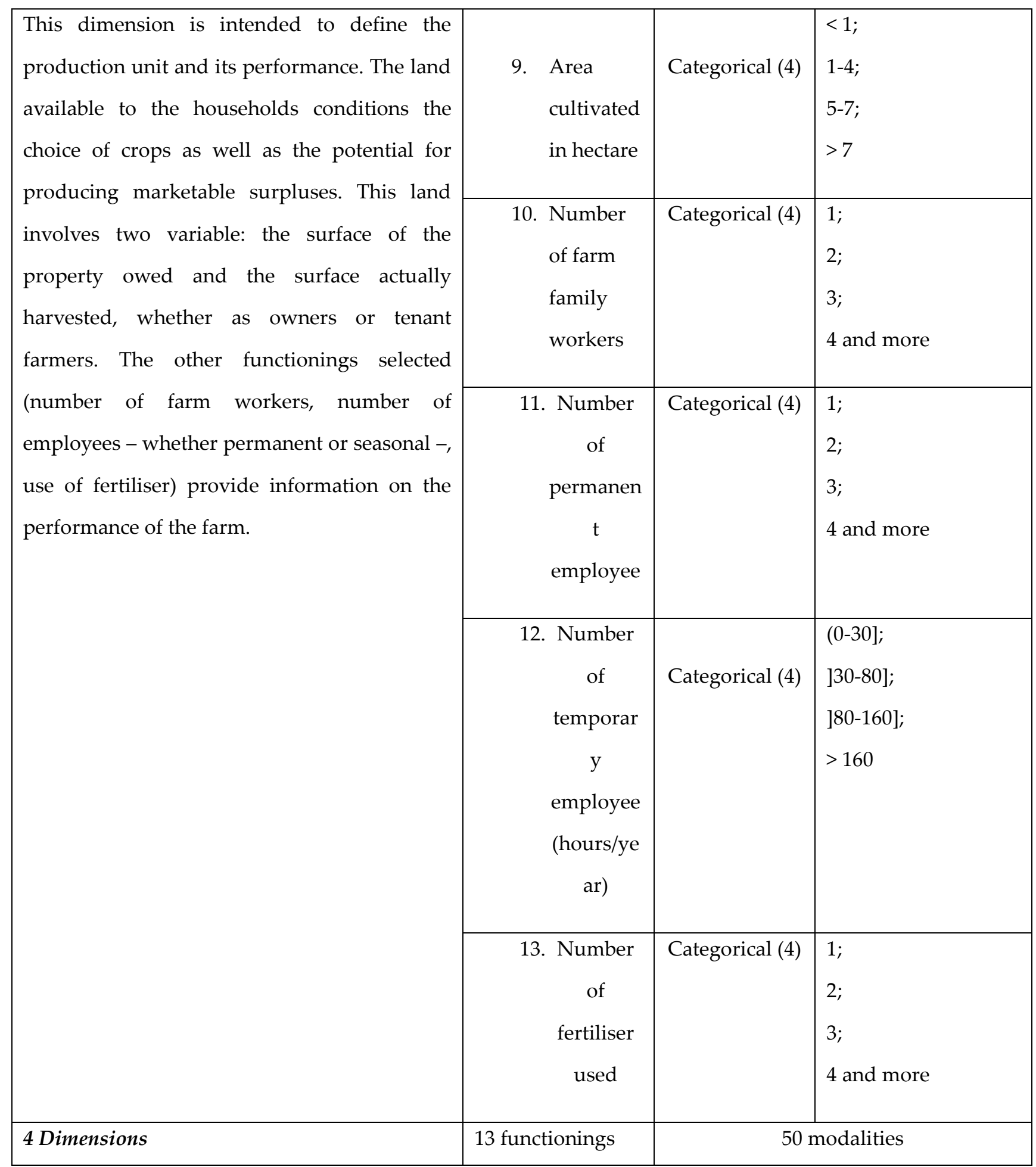

- $\left(10^{3}\right.$ Ariari) 


\section{Appendix B. Alternative selection of functionings dimensions more relevant}

\section{(\% of inertia)}

This alternative arrangement of functionings assumes that the "family workers" are affected to the human dimension drawing on the idea that wathever the use of their working force, they define the household structure. Within this another arrangement, the distribution of inertia brings out the same both dimensions of production and security.

\begin{tabular}{|r|c|c|r|}
\hline Functioning & Dimension & Axe 1 & Axe 2 \\
\hline $\begin{array}{r}\text { House size } \\
\text { Age of household }\end{array}$ & & & \\
Family farm workers & Human & 28,08 & 15,39 \\
\hline $\begin{array}{r}\text { Area cultivated } \\
\text { Temporary employees } \\
\text { Use of fertiliser }\end{array}$ & Production & 42,63 & 19,83 \\
\hline $\begin{array}{r}\text { Cash saving } \\
\text { Disposable income }\end{array}$ & Income & 7,36 & 30,11 \\
\hline $\begin{array}{r}\text { Diversification } \\
\text { Self-sufficiency in rice } \\
\text { Asset }\end{array}$ & Security & & \\
\hline
\end{tabular}


Appendix C. The Brandt test

\begin{tabular}{|l|l|l|l|}
\hline & chi2 & $\mathbf{p}>\mathbf{c h i 2}$ & $\mathbf{d f}$ \\
\hline All & 14.01 & 0.007 & 4 \\
\hline Number of loans & 5.08 & 0.024 & 1 \\
\hline Life-cycle events & 0.19 & 0.663 & 1 \\
\hline Very good harvest & 4.74 & 0.030 & 1 \\
\hline Gender & 4.38 & 0.036 & 1 \\
\hline
\end{tabular}

A significant test statistic provides evidence that the parallel regression assumption has been violated. 
Appendix D. The statistic descriptive of regressions variables of the three capability levels

\begin{tabular}{|c|c|c|c|c|c|c|c|}
\hline Variables & $\begin{array}{l}\text { Level of } \\
\text { capability }\end{array}$ & Obs & Mean & Std. Dev & Min & Max & Type of variable \\
\hline $\begin{array}{l}\text { Microcredit } \\
\text { loan amount } \\
\text { in } 2006\end{array}$ & $\begin{array}{l}1 \\
2 \\
3 \\
\end{array}$ & $\begin{array}{l}67 \\
160 \\
63 \\
\end{array}$ & $\begin{array}{l}156421.6 \\
373530.9 \\
1529294 \\
\end{array}$ & $\begin{array}{l}354606.8 \\
611744.7 \\
3773041 \\
\end{array}$ & $\begin{array}{l}0 \\
0 \\
0\end{array}$ & $\begin{array}{l}1500000 \\
3950000 \\
29232000\end{array}$ & Monetary \\
\hline $\begin{array}{l}\text { Number of } \\
\text { loan } \\
\text { [2003-2006[ }\end{array}$ & $\begin{array}{l}1 \\
2 \\
3 \\
\end{array}$ & $\begin{array}{l}67 \\
160 \\
63 \\
\end{array}$ & $\begin{array}{l}0.33 \\
0.91 \\
1.11 \\
\end{array}$ & $\begin{array}{l}0.68 \\
1.03 \\
1.05 \\
\end{array}$ & $\begin{array}{l}0 \\
0 \\
0\end{array}$ & $\begin{array}{l}3 \\
3 \\
3 \\
\end{array}$ & Numerical \\
\hline $\begin{array}{l}\text { Years of } \\
\text { membership }\end{array}$ & $\begin{array}{l}1 \\
2 \\
3\end{array}$ & $\begin{array}{l}67 \\
160 \\
63 \\
\end{array}$ & $\begin{array}{l}7.44 \\
7.93 \\
6.97\end{array}$ & $\begin{array}{l}2.37 \\
2.95 \\
2.57\end{array}$ & $\begin{array}{l}1 \\
0 \\
1\end{array}$ & $\begin{array}{l}13 \\
13 \\
13\end{array}$ & Numerical \\
\hline Education & $\begin{array}{l}1 \\
2 \\
3\end{array}$ & $\begin{array}{l}67 \\
160 \\
63\end{array}$ & $\begin{array}{l}2.79 \\
3.21 \\
2.79\end{array}$ & $\begin{array}{l}0.99 \\
0.85 \\
1.02\end{array}$ & $\begin{array}{l}1 \\
1 \\
1\end{array}$ & $\begin{array}{l}4 \\
4 \\
4\end{array}$ & $\begin{array}{l}\text { Categorial } \\
1=\text { None } \\
2=\text { Primary } \\
3=\text { lower sec } \\
4=\text { up. sec. } \&+\end{array}$ \\
\hline $\begin{array}{l}\text { Expense for } \\
\text { Life-cycle } \\
\text { events }\end{array}$ & $\begin{array}{l}1 \\
2 \\
3\end{array}$ & $\begin{array}{l}67 \\
160 \\
63\end{array}$ & $\begin{array}{l}3.31 \\
2.95 \\
2.67\end{array}$ & $\begin{array}{l}0.89 \\
1.09 \\
1.22\end{array}$ & $\begin{array}{l}1 \\
1 \\
1\end{array}$ & $\begin{array}{l}4 \\
4 \\
4\end{array}$ & $\begin{array}{l}\begin{array}{l}\text { Categorical } \\
1=<1000 \\
2=] 1000-100000] \\
3=] 100000-300000 \\
4=>300000\end{array} \\
\end{array}$ \\
\hline Gender & $\begin{array}{l}1 \\
2 \\
3\end{array}$ & $\begin{array}{l}67 \\
160 \\
63\end{array}$ & $\begin{array}{l}0.46 \\
0.69 \\
0.68\end{array}$ & $\begin{array}{l}0.50 \\
0.46 \\
0.47\end{array}$ & $\begin{array}{l}0 \\
0 \\
0\end{array}$ & $\begin{array}{l}1 \\
1 \\
1\end{array}$ & Dichotomous \\
\hline $\begin{array}{l}\text { Very good } \\
\text { harvests }\end{array}$ & $\begin{array}{l}1 \\
2 \\
3 \\
\end{array}$ & $\begin{array}{l}67 \\
160 \\
63 \\
\end{array}$ & $\begin{array}{l}0.27 \\
0.49 \\
0.48 \\
\end{array}$ & $\begin{array}{l}0.45 \\
0.50 \\
0.62 \\
\end{array}$ & $\begin{array}{l}0 \\
0 \\
0\end{array}$ & $\begin{array}{l}1 \\
1 \\
1 \\
\end{array}$ & Dichotomous \\
\hline $\begin{array}{l}\text { Verry poor } \\
\text { sales prices }\end{array}$ & $\begin{array}{l}1 \\
2 \\
3\end{array}$ & $\begin{array}{l}67 \\
160 \\
63\end{array}$ & $\begin{array}{l}0.12 \\
0.17 \\
0.35\end{array}$ & $\begin{array}{l}0.33 \\
0.38 \\
0.60\end{array}$ & $\begin{array}{l}0 \\
0 \\
0\end{array}$ & $\begin{array}{l}1 \\
1 \\
1\end{array}$ & Dichotomous \\
\hline
\end{tabular}

